\title{
Current Scenario of Electric Mobility in India and its Challenges
}

\author{
Nayan Madhav Sarode \\ Department of Mechanical Engineering, \\ Dr. Babasaheb Ambedkar Technological University, \\ Lonere, Raigad India 402103
}

\author{
M. T. Sarode \\ Department of Physics, \\ Mahatma Phule Mahavidyalya, \\ Pimpri Pune, India 411017
}

\begin{abstract}
Electric mobility revolution is considered as a biggest revolution for automotive industrial sector. This revolution came into existence due to depletion of crude oil, fossil fuels, natural gas etc. To overcome this crisis many technologies have been developed by different nations in our world. But there is not much awareness about electric mobility among people in India so that they can use this technology. As this technology is new to people living in India there are many difficulties faced by automotive industries to design electric vehicle which will be affordable and suitable for people. Automotive industries of India are trying to improve battery technology by which they can increase range of electric vehicles to make it affordable and efficient. There is lack of charging stations in India moreover average charging time for an electric vehicle is more due to which people are finding it difficult to use electric mobility for their daily usage. A vehicle having less charging time is not affordable to everyone. Government of India is also implementing different policies for electric mobility to reduce pollution and decrease use of fossil fuels made by transportation. Government is also creating awareness among people for using electric vehicle instead of fuel vehicles.
\end{abstract}

Keywords--- Fuel vehicle, regenerative braking system, Internal Combustion Engine(IC engines), battery electric vehicle (BEV), Electric vehicle.

\section{I.INTRODUCTION}

Electric vehicles technology came into existence since 1837 in Scotland by Robert Anderson [1]. He made a first electric crude vehicle which works on both electric motor and crude engine [1]. After that many scientist performed different research and invented different electric vehicle. Each vehicle would have more improvement compared to previous electric vehicle. Scientist made improvements in battery technology, electric motor which improved efficiency and speed of vehicle day by day. But after some years internal combustion engines (IC Engines) were introduced in automobile sector due to which speed of vehicle became more than the speed which electric vehicle were giving. So, due to this IC engines technology there was a break to electric mobility technology and scientist started their research on IC engine vehicles. After many years due to excessive use of crude oil, fossil fuels and natural gas by fuel vehicles there was depletion in this fuels sources. This made automobile sector's to introduce electric mobility technology again. Electric vehicles were used in many nations earlier. But in India electric vehicles was introduced in the year 2011 by Mahindra electric mobility Ltd. And Reva electric company car i.e. Revai electric car [2]. This car was equipped with lead-acid battery which gave range of $80 \mathrm{~km}$ per charge [2]. Its top speed was $80 \mathrm{~km} / \mathrm{h}$ [2]. After this Mahindra introduced different electric vehicles in India. Electric mobility started getting importance in India but less than expected as people were expecting more improvement from it. Indian scientists are doing research to improve factors that makes electric vehicle compatible for daily usage. The electric vehicle having more efficiency is expensive which cannot be afforded by common people. Also on an average electric vehicle requires minimum 8-9 hours to charge from $20 \%$ to $80 \%$ moreover range of such electric vehicle is very less which make it incompatible for daily usage. And also in India there is less charging station where people can charge their electric vehicle when they are travelling long distances. Due to these parameters there are fewer sales of electric vehicles in India. Electric vehicle require more charging time and less range due to less improvement in battery technology. First battery introduce for electric vehicle was lithium-ion battery in roadster battery electric vehicle (BEV) [1]. But lithium-ion battery was having less capacity due to which range of electric vehicle were less. After scientists performed different research and made improvement in battery technology. To reduce charging time. Rapid chargers were introduced due to which battery was charged in less time. But in some nations rapid charging is provided only by charging stations of electric vehicles. In India there is less charging station compared to other nation due to which people cannot charge their vehicle for more time and use it daily. Government in India is implementing different policies to make people aware about using electric mobility's. Government has started 'National Electric Mobility Mission' (NEMM) from the year 2020 [3]. In this mission government is going to introduce electric vehicle to people and increase usage of electric vehicle in India [3]. For this government has also introduce 'Faster Adoption and Manufacturing of Hybrid and Electric Vehicle' (FAME) in which they have taken some measures for reducing cost of electric vehicle and increase its sale in India [3]. This will increase awareness about importance of electric vehicle in India.

\section{II.AWARENESS OF ELECTRIC MOBILITY IN INDIA}

India is the only country where electric vehicle was introduced late than other countries. Due to which Indian people are not aware about electric mobility technology as this technology is new to people and they didn't have much knowledge about it. Due to which people think that instead 
of taking expensive electric vehicle it is better to take fuel vehicles which does not depend on charging of battery for mobility. As Indian people have mentality that vehicle should have good mileage or efficiency so for that they always compare vehicles on the basis of mileage given by vehicle. Indian researchers are trying to improve range of electric vehicle. So that cost of them will be affordable to people and they will get better option than fuel vehicle.

Due to climate change people are getting aware about the energy crisis which they can face in future. So people had started to focus on green energy due to which there will be decrease in pollution level. As electric mobility technology is a step towards green technology which will help to reduce pollution in our world. As electric vehicles are zero emission vehicle government has also started implementing different policies to motivate people to move towards green energy sources.

\section{III.BATTERY TECHNOLOGY IN INDIA}

India's first electric vehicle uses Lithium-Ion battery but it has many drawbacks such as short range, less battery life, etc. It is a two-seater car how people can afford such car that has such a low range. Fuel vehicles can be filled with fuel at fuel station wherever they want. But due to less availability of charging station electric vehicles cannot be charged again and again while travelling. And also in most of the electric vehicles batteries are stored at bottom side of electric vehicle due to which there is reduction in interior space and also ground clearance. Some people think that as batteries are located at bottom it can get damage during rainy season or at water logged areas. But most of the companies do water test before launching a new vehicle and then only they launch it in market [9]. So people should not avoid buying electric vehicle due to water problems.

Types of batteries are:-

A. Lead-Acid Battery

Battery used in first electric vehicle of world was a lead-acid battery [1]. It is a rechargeable battery which is composed of pure lead at negative side and lead dioxide $\left(\mathrm{PbO}_{2}\right)$ with sulfuric acid at positive side of battery. LeadAcid battery has both automobile and Industrial benefits and applications. It is been used in vehicles for small scale applications like providing power to headlight, engine starter, Air conditioner fan, speedometer, etc.[4]. Due to less cost and high efficiency most of the automobile industries prefer to use lead-acid battery technology in their vehicle's as it decrease cost of vehicle and become profitable to customers. Lead-Acid battery uses gel technology due to which battery is prevented from leakage issue and it also increases life of battery [4].

Lead-Acid battery were having drawbacks like while charging it emits hydrogen gas which can cause explosion as hydrogen is highly flammable compound. And also leadacid battery is made up of many chemical compounds which are harmful to environment. To avoid these drawback researchers developed new batteries such as Nickel-Cadmium, Nickel- Metal hydride, Lithium-sulfur, Lithium-air, Lithium-Ion, etc. But among these batteries researchers started using lithium-Ion batteries as a source of power.

\section{B. Lithium-ion Battery}

Lithium-ion battery is a rechargeable battery. It is made of carbon negative electrode, positive electrode is metal oxide and electrolyte is lithium salt in organic solvent. It can stored in four different shapes i.e. there are four types of shapes of lithium-ion battery. Lithium ion batteries have high storage capacity then other batteries. When it is fully charged it gives output up to $4 \mathrm{~V}$ and it have discharge rate of 3 Vwhich is better than other batteries [5]. Due to high capacity it is used by most of the electric vehicles in India and other countries. Lithium-Ion batteries are expensive and heavy due to which cost of the electric vehicle increases. And common people in India cannot afford such cars. Also lithium ion batteries can explode if not charged in correct manner or damaged. So there is risk for using lithium ion batteries that is taken by electric vehicle companies. Due to this drawbacks there is problem faced by automobile industries for using these batteries. After using lithium-ion batteries and due to its drawbacks researcher started to improve battery technology. In this researchers introduced fuel-cell as an alternative for these problems.

\section{Fuel Cell}

Fuel- cell is an electricity providing device which consists of anode and cathode. Most of the fuel cell contains a fuel and an oxide which perform redox reaction to give energy. Majorly hydrogen is used as a fuel and oxygen as an oxide in fuel cell which perform reaction. There are many types of fuel cells such as proton-exchange membrane fuel cell (PEMFC), Phosphoric acid fuel cell (PAFC), Solid Acid Fuel Cell (SAFC), Alkaline Fuel Cell (AFC), etc.[6]. Fuel cell continuously requires supply of fuel and oxygen to produce energy. It has better efficiency than other batteries and can be used to get high range and also affordable.

Korea has used fuel cell for their E-buses which have given a good impact on automobile industry [7]. In 2018 India has also launched electric bus which works on fuel cell which was launched in New Delhi [8]. But hydrogen and oxygen fuel-cell requires hydrogen as a fuel and hydrogen is highly flammable substance and it can be harmful to people due to which it is not used in most of the electric vehicles. But if we take precaution and try to develop fuel cell technology to avoid explosion then fuel cell will be the best alternative for power source required in electric vehicles.

There is need to develop battery technology not only in India but also in other countries as battery is the main component of electric vehicle and it cannot work without it. As range of vehicle, features, cost of vehicle depends on which batteries are used and how much efficiency it gives. For example if electric vehicle uses batteries having better efficiency and provide more range then people would buy that vehicle and not the vehicle which has less range and more cost. People have a mentality that electric vehicle should be less expensive but can travel large distances in one charge. 


\section{IV.CHARGING STATION FOR ELECTRIC VEHICLES IN INDIA}

Charging station for electric vehicle is very important factor as without it people cannot travel longer distances using electric vehicle. The charger provided with electric vehicle is normal charger which requires more time to charge battery fully. But charging station provides rapid charging due to which battery gets charged fully in very less time compare to other charging mediums. As in electric vehicle normal chargers are AC chargers with one or three phases in which AC is converted into DC using own converter whereas rapid or fast charger are DC charger where there is no requirement of conversion. Due to this most of the people will prefer charging their electric vehicle in charging stations as it can save their time.

Charging stations were established as it was the only source for charging electric vehicle when travelling. For constructing a charging station large amount of space and finance is required. And as in India many fuel stations are established due to which establishing charging station is difficult. The charging cable supports both normal and fast charging. The cable is secure in rainy season also. As some people think that it is dangerous to charge electric vehicles while it's raining as water and electricity combination is harmful which can cause major accidents. But electric vehicle chargers are weatherproof which protects vehicle and human both from electric shock [9].

There are four types of charging station for electric vehicle:-

\section{A. Residential charging station}

These are charging station build in our residential area where we can charge our vehicle whenever we want. It uses normal charging which takes approximately eight to nine hours. The connection given is either two phase or three phase and charger used is AC charger. These charging stations are used when people are having free time for example we can use this for charging our vehicle daily when we come back from our work and charge vehicle in free time. In India Tata Company car Nexon EV is providing with own charging station which we can build in the area where we park our vehicle and charge there [10]. It also provides charging cable for normal charging only and if we want to use fast charging technology it is provided at charging stations only [10].

\section{B. Charging Station at Parking}

We can use this charging station by paying fee and charge our vehicle while in parked area. These charging stations are available in some countries but not in India. India should make this station at mall parking lot which will be made available to most of the people.

\section{Fast Charging Station}

It has capacity of more than $40 \mathrm{KW}$ [10]. It can be used when someone is having less time to wait for charging vehicle. These are built in long route areas due to which people travelling for a long distance can use it and prevent waiting in a que for charging their electric vehicles. These types of charging station are available in some countries and very few in India. Fast charging has brought a drastic change in charging field due to which people can save their time.

\section{Battery Swapping Centres}

An alternative for charging station problems some automobile industries had established battery replacement centres where people using electric vehicle can give their discharged battery and pay some amount to take charged battery. This is an automated mechanism which save large amount of time and also it is sometimes better than fast charging. For example Revolt Company of bike has launched this system of battery replacement in India and other countries [11]. Many battery replacement centres of Revolt Company are established in India which has helped to increase sale of this electric vehicle. This alternative method is better but it causes wastage of batteries and also decreases life of battery.

Many countries are using electric vehicles before India due to which they have established many charging stations in their areas. But as India has not completely shifted from fuel vehicles to electric vehicles they have very few charging stations due to which people cannot travel long distances. Moreover range of electric vehicle is also less so people think that instead charging an electric vehicle again and again they choose to use fuel vehicles. There is a need to increase charging stations in India as government is planning to shift towards green energy which can only be possible by using electric vehicle. Government is also implementing different policies to construct charging stations. As less amount of charging station and low range of electric vehicle are major drawbacks in India which should be solved.

\section{V.RESEARCH AND DEVELOPMENT OF ELECTRIC MOBILITY TECHNOLOGY IN INDIA}

Research and development in electric vehicle sector is very important now as it is the only sector which can reduce large amount of pollution and also save fossil fuels from depletion. Most of the researchers are focusing to improve battery technology as it is the major part of electric vehicle and the main factor range depends on battery efficiency. So researchers are trying to improve battery efficiency so that range of vehicle can be increase and it will be affordable to people. Researchers are also trying to reduce charging time of battery and save time of people for charging their electric vehicle. As in many places people do not have access to charging station in India.

After many research automobile industries started using lithium-ion batteries which were better than previous batteries. Lithium-ion batteries created a big impact in automobile sector and every company started using lithium-ion battery in their vehicles. And it has made many improvements in electric vehicle design. But there were some drawbacks of lithium-ion battery due to which researchers are trying to develop lithium ion battery by changing metal ion in them. Researchers introduced fuelcell as an alternative for batteries in which metal compounds were used as a fuel which reacts with metal oxide and generates energy but it was very harmful as the fuel used was hydrogen which was highly flammable and can cause damage. 


\section{A. Sodium-Sulfur Battery Technology}

Sodium-Sulfur battery is a molten-salt type battery which consists of liquid sodium and sulfur [14]. These batteries have high capacity and efficiency which is better than lithium-ion batteries so it can be used instead of lithium-ion batteries in electric vehicles. But sodium sulfide present in sodium-sulfur battery is highly corrosive in nature which can reduce the life of battery [14]. Due to this automobile industries are not using sodium-sulfur batteries. In India most of the products uses lithium-ion battery only. And also researchers are trying to improve battery technology by replacing ions of lithium-ion battery to other compounds ion which can make it more efficient and durable.

\section{B. Lithium-Air Battery Technology}

Researchers are now focusing on lithium-air battery technology. IBM has claimed that it can give a range of $800 \mathrm{~km}$ without charging the battery [12]. So it will be a biggest invention in battery technology and electric vehicle sector. Lithium-air battery is a combination of metal i.e. lithium and oxygen electrochemical cell or battery. In this oxidation of lithium occurs at anode and reduction of oxygen occurs at cathode. These batteries can also increase technologies to be used in electric vehicle design and also reduce cost of vehicle. It is said that lithium-air cells could offer range equivalent to normal fuel vehicles with a battery pack of one-third the size of fuel tanks [12]. Lithium-air batteries have low cost which can make electric vehicles affordable and efficient to people.

\section{Solar-Powered Electric Vehicle}

Research is also going on solar energy powered electric vehicle in which solar energy can be used to charge batteries of electric vehicle. But as the cost of solar panels is more it can increase the cost of electric vehicle which is the reason why solar powered electric vehicles are not manufactured. There is also scope for research in green energy area which can improve this technology.

\section{Regenerative Braking System}

Researchers are trying to use regenerative braking system to charge the battery. In this kinetic energy or heat energy is produced when we apply brakes to a vehicle in motion which is converted into electrical energy that is provided to batteries for getting charged. But the energy generated through regenerative braking system is very less which cannot charge much part of battery. So it cannot be better solution to improve efficiency of electric vehicle.

\section{E. Bi-directional Charging System}

There is a research going on for improving charging methods due to which batteries can be made efficient. One of the research topics is bi-directional charging in electric vehicle. In this charger can supply energy in two directions. In normal electric vehicle charger the AC supply of house or parking where electric vehicle is charged is converted into DC by vehicles own converter or by charger. But in bi-directional the energy from battery can be extracted and put back into house supply in which the DC energy should be converted into AC supply that can be added to house [13]. The supply of energy from house to electric vehicle is referred as vehicle to grid (V2G) and the supply from battery to house is referred as vehicle to home (V2H) [13]. This technology prevents wastage of energy caused due to overcharging of batteries.

\section{VI.GOVERNMENT MEASURES TAKEN TO PROMOTE ELECTRIC MOBILITY IN INDIA}

Government of India is trying to implement different policies or scheme to promote green energy. As we know that due to pollution there is need of green energy which can reduce problems that has arisen due this pollution. Government is giving scheme through which people can take electric vehicle in low cost. Government of India has launched 'National Electric Mobility Mission 2020' through which they are providing incentives to reduce cost of electric vehicle and increase sale of it in India [2]. Niti Ayog of India plans about the policies which are implemented for electric mobility by government. And also Niti Ayog is trying their best to improve condition of sale of electric vehicles in India.

Government has started these missions since 2010 which was provided incentives MNRE for schemes related to electric vehicle but this was withdrawn in March 2012 to introduce it as 'National Electric Mobility Mission Plan 2012' (NEMMP 2012) [2]. Government has a mission that all Indian people should have their own electric vehicle and put a step forward towards green future till the year 2030 [2]. Government is planning to introduce electric buses, two wheelers, and three wheelers before other types of vehicles. But due to some drawbacks in electric vehicle and shortage of charging station people are buying fuel vehicle instead of electric vehicle.

Government should plan to increase charging stations in India as due to shortage of charging station people cannot travel long distances using electric vehicle having less range. They can establish charging station at fuel pump, parking area where vehicles are standing ideal for long time. Government and automobile industries are trying to increase battery swapping centres to save time for charging electric vehicle.

\section{RESULTS AND DISSCUSSION}

Table 1: Production of Vehicles in India [5]

\begin{tabular}{|c|c|c|c|c|c|c|c|}
\hline Category & $\mathbf{2 0 0 6 - 0 7}$ & $\mathbf{2 0 0 7 - 0 8}$ & $\mathbf{2 0 0 8 - 0 9}$ & $\mathbf{2 0 0 9 - 1 0}$ & $\mathbf{2 0 1 0 - 1 1}$ & $\mathbf{2 0 1 1 - 1 2}$ & $\mathbf{5 - y r ~ C A G R ( \% )}$ \\
\hline $\begin{array}{c}\text { Passenger } \\
\text { Vehicles }\end{array}$ & $1,545,223$ & $1,777,583$ & $1,838,593$ & $2,357,411$ & $2,982,772$ & $3,123,528$ & 15.11 \\
\hline $\begin{array}{c}\text { Commercial } \\
\text { Vehicles }\end{array}$ & $5,19,982$ & $5,49,006$ & $4,16,870$ & $5,67,556$ & $7,60,735$ & $9,11,574$ & 11.38 \\
\hline Two Wheelers & $84,66,666$ & $80,26,681$ & $84,19,792$ & $10,512,903$ & $13,349,349$ & $15,453,619$ & 12.79 \\
\hline $\begin{array}{c}\text { Three } \\
\text { Wheelers }\end{array}$ & $5,56,126$ & $5,00,660$ & $4,97,020$ & $6,19,194$ & $7,99,553$ & $8,77,711$ & 9.56 \\
\hline Grand Total & $11,087,997$ & $10,853,930$ & $11,172,275$ & $14,057,064$ & $17,892,409$ & $20,366,432$ & 12.93 \\
\hline
\end{tabular}




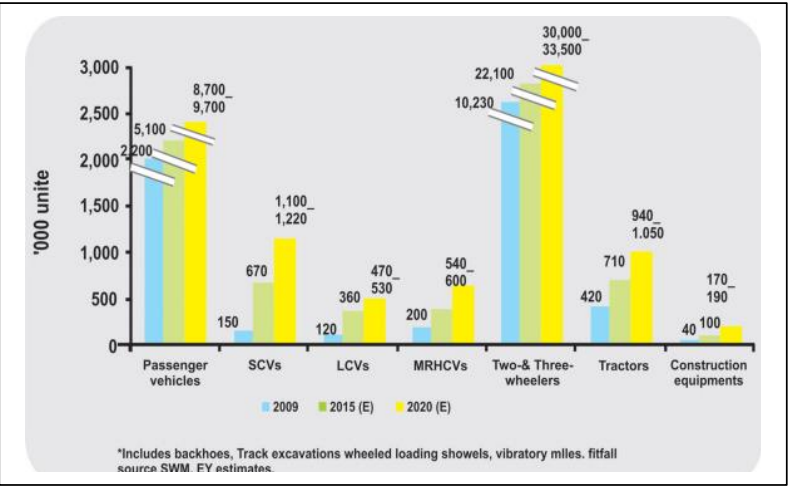

Fig. 1. Electric Vehicle Production [5]

From table 1 it can be seen that there is huge amount of production of fuel vehicle in India and also CAVG is given in percentage for 5 years

Fig. 1 shows the production rate of different types of vehicles in India.

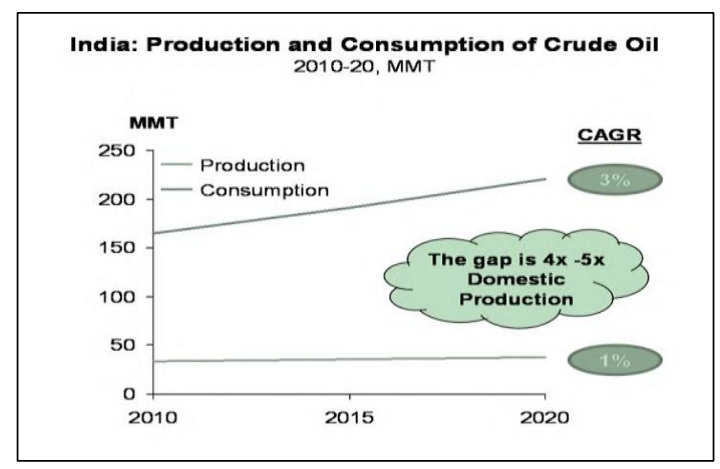

Fig. 2. Graphical Representation of Production and Consumption of Crude Oil in India [5]

From fig. 2 it can be concluded that consumption of crude oil is increasing with respect to year and production rate is very less and constant throughout the years.

\section{A. Charging Stations Available in India}

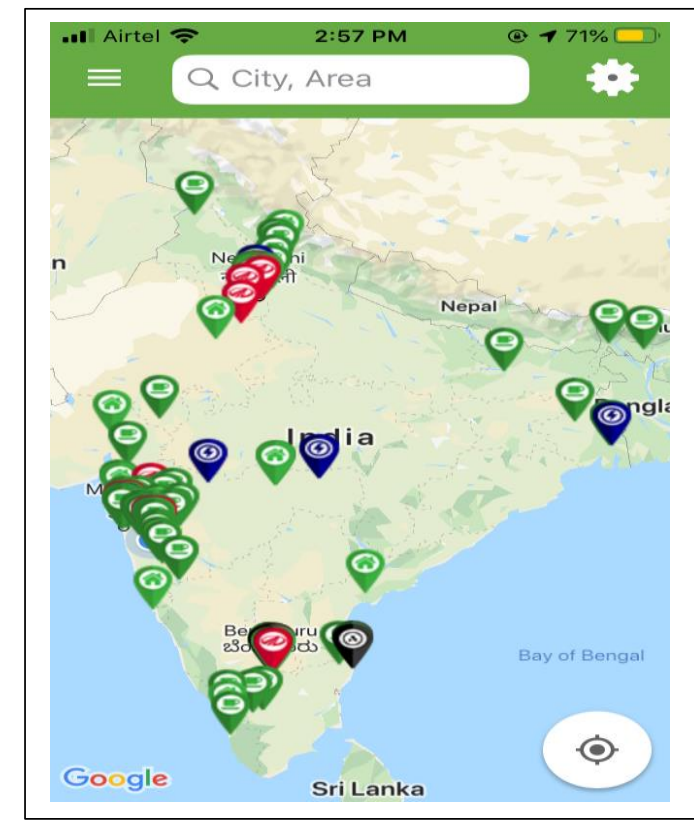

Fig.4.Electric Vehicle Charging Station Available in India (As per Recharge India- EV Charging point's map) [15]
As per data provided by electric vehicle community there are in total 164 charging stations of electric vehicle in India which are tracked by 'Recharge India- EV Charging point's map' and shown in the form of map [15]. From this data it can be concluded that number of charging station is very less compare to other countries which makes India lack behind in development of electric mobility in India.

\section{B. Sale of Electric Vehicles per Year}

As per data provided by Society of Manufacturing Electric Vehicles report a total of 1.56 lakh units of electric vehicles were sold in India during the last financial year as compared to 1.3 lakh in financial year 2018-19 [16].This report does not considered e-rickshaw as they are in unorganised sector [16]. However, an estimate of 90,000 erickshaws was sold in India during last financial year. Electric Vehicle sale in India registered 20 percent growth in financial year 2019-2020 as opposed by financial year 2018-2019 [16]. From this data it can be concluded that due to increase in awareness of electric mobility in India there is increase in sale per year compared to previous year.

\section{Data Taken From 'National Electric Mobility Mission Plan 2020' About Planning of Government of} India

In order to promote the sale of electric vehicles in the Indian market, the government launched FAME (Faster Adoption and Manufacturing of Hybrid and Electric vehicles) scheme in India, as a part of the National Electric Mobility Mission Plan 2020, under which, the government would provide certain incentives to lower the purchasing cost of electric vehicles, [2]

Overall, the government is expected to spend around ₹ 14,000 Crores for this scheme, which includes incentives to the customers for purchasing electric vehicles, incentives to the manufacturers for research and development besides developing the charging infrastructure. [2]

During the financial Year 2015-16, an amount of ₹ 75 Crores was allocated for this scheme, which was almost fully utilised. In the last financial year (2016-17), ₹ 91 Crores (approx.) has been utilised out of the budget allocation of ₹ 122.90 Crores. [2]

Under phase 1 of this scheme, support was extended to buyers during the fiscal years 2015-16 (₹ 260 Crores) and 2016-17 (₹ 535 Crores). Further incentives would be provided depending upon the success of phase 1. [2]

Incentives of about ₹ 33 to 66 Lakhs are planned for each electric bus which typically costs around ₹ 1-2 Crores (imported buses) and around ₹ 50-80 Lakhs (domestically manufactured). [2]

Under the JNNURM (Jawaharlal Nehru National Urban Renewal Mission), NEMMP (National Electric Mobility Mission Plan) and Smart city plans launched by the government, various state and local transport bodies are expected to purchase electric buses over the next 5years. [2].

\section{VIII.CONCLUSION}

From the above study it can be concluded that electric mobility technology is introduced late in India compare to other countries. And Indian people are finding 
difficult to adjust with this new technology. As if they buy an electric car they cannot use them for daily basis or to travel for a long distances. The reason behind this is poor battery technology which provides less range and requires more time to charge completely. And also there is shortage of charging stations in India where people can charge their vehicles. Automobile industries have introduced alternative to this i.e. battery swapping system but it also has its own drawbacks. Indian people tend to buy vehicle which is affordable and can be used on daily basis. But as the prices of electric vehicle is two high with less range people does not find it affordable to use instead of fuel vehicles. Government is also trying to promote green energy by introducing electric vehicles but due to limitations of this technology in India there is less impact of it. People are also having some myths like using electric vehicle in rainy atmosphere or area having water logging is dangerous. Due to these misconceptions or lack of knowledge about electric mobility technology there is less usage of electric vehicle in India.

\section{ACKNOWLEDGEMENT}

The author Nayan Madhav Sarode is thankful to Dr. Madhav Sarode Professor Department of Physics Mahatma Phule Mahavidyala, Pimpri for providing guidance.

\section{REFERENCES}

11] https://en.wikipedia.org/wiki/History_of_the_electric_vehicle

[2] A.K. Digalwar , Ganneri Giridhar "Interpretive Structural Modeling Approach for Development of ElectricVehicle Market in India", ScienceDirect, Procedia CIRP Vol.26 , 40 - 45, 2015

[3] Department of Heavy Industry Ministry of Heavy Industries and Public Enterprises Government of India Manual On "National Electric Mobility Mission Plan 2020"

[4] https://en.wikipedia.org/wiki/Lead\%E2\%80\%93acid_battery

[5] Snigdha Sharma, Amrish K. Panwar, M.M. Tripathi, "Storage Technologies for Electric Vehicles", Journal of traffic and transportation engineering (english edition ) 302,JTTE 302, 2020

[6] M. Muthukumar, N. Rengarajan, B. Velliyangiri, M.A. Omprakas, C.B. Rohit, U. Kartheek Raja , "The development of fuel cell electric vehicles - A review", Material Today: Proceeding, November 2019.

[7] https://www.sustainable-bus.com/fuel-cell/hyundai-fuel-cellhydrogen-bus-south-korea/

[8] https://energy.economictimes.indiatimes.com/news/oil-andgas/indias-first-hydrogen-fuel-cell-powered-bus-flagged-off-byioc/63272303

[9] https://www.financialexpress.com/auto/electric-vehicles/electricvehicle-safety-during-monsoon-ev-myth-electric-cars-tata-nexonev-hyundai-kona-ev/2029398/

[10] https://en.wikipedia.org/wiki/Charging_station

[11] https://economictimes.indiatimes.com/industry/auto/two-wheelersthree-wheelers/all-we-know-about-ai-enabled-revolt-rv-400motorcycle/battery-swap/slideshow/70059122.cms

[12] https://en.wikipedia.org/wiki/Lithium\%E2\%80\%93air_battery

[13] https://wallbox.com/en_us/bidirectional-ev-charger

[14] https://en.wikipedia.org/wiki/Sodium\%E2\%80\%93sulfur_battery

[15] https://www.pluginindia.com/charging.html

[16] https://www.timesnownews.com/auto/features/article/electricvehicle-sales-in-india-registered-a-healthy-20-growth-in-fy2019/580817\#: :text=As\%20per\%20SMEV's\%20report\%2C\%20a, to $\% 20$ push $\% 20$ for $\% 20$ cleaner\%20mobility. 